\title{
KONSEP PARTISIPASI MASYARAKAT DALAM PEMBENTUKAN PERATURAN DAERAH RENCANA DETAIL TATA RUANG DAN KAWASAN
}

\author{
Oleh: Tomy M Saragih
}

\begin{abstract}
Organizing public participation in spatial planning becomes very important and needs to be considered in the process of spatial planning, both in the planning process, utilization, space utilization and control to minimize conflicts between interested parties.
\end{abstract}

Keywords: Community Participation, Local Rules, Detailed Spatial Plan and Regions

\section{A. LATAR BELAKANG.}

Partisipasi masyarakat (public participation) pada tatanan pemerintahan yang demokratis menghendaki adanya keterlibatan publik dalam proses pengambilan keputusan (decision-making process) yang semakin penting di era otonomi daerah. Pelaksanaan otonomi daerah berdasarkan Undang-Undang Republik Indonesia Nomor 32 Tahun 2004 tentang Pemerintahan Daerah (UU No. 322004), telah membawa perubahan besar dalam setiap segmen penyelenggaraan Pemerintahan Daerah. ${ }^{1}$

Di dalam kurun waktu pelaksanaan otonomi daerah, pemerintahan daerah ditengarai banyak melakukan penyimpangan dan kesalahan persepsi mengenai otonomi daerah. Sebagian besar implementasi undang-undang pemerintahan daerah hanya mengedepankan orientasi keuangan dengan menciptakan berbagai peraturan daerah (perda) yang menekankan kepentingan ekonomi daripada kepentingan pelayanan publik. Berbagai kasus pembatalan perda yang dilakukan pemerintahan pusat akhirnya

${ }^{1}$ Soekarwo. 2005. Hukum Pengelolaan Keuangan Daerah Berdasarkan Prinsip-Prinsip Good

Financial Governance. Surabaya, Airlangga University Press, hlm. 2-7. muncul sebagai suatu kenyataan yang mesti di terima oleh pemerintah daerah. ${ }^{2}$ Banyak perda yang telah dibatalkan oleh pemerintah pusat karena dianggap bertentangan dengan peraturan perundang-undangan dan memberatkan publik. ${ }^{3}$ Kenyataan tersebut merupakan suatu realitas faktual dari kecenderungan yang justru tidak sesuai dengan semangat dan filosofi otonomi daerah berdasarkan UU No. 32-2004 untuk meningkatkan kesejahteraan rakyatnya. Tegasnya otonomi daerah telah dipahami secara salah dan melenceng dari spirit aslinya yang hendak mengembangkan kondisi yang menjadi potensi lokal (daerah).

Sebagaimana tercantum dalam Undang-Undang Republik Indonesia Nomor 26 Tahun 2007 tentang Penataan Ruang (UU No. 26-2007) bahwa tujuan dari penataan ruang adalah mewujudkan penataan ruang yang aman, nyaman, produktif dan berkelanjutan yang pada akhirnya bermuara kepada kesejahteraan masyarakat. Sehubungan dengan hal tersebut, maka peran serta masyarakat dalam penyelenggaraan penataan ruang menjadi sangat penting dan perlu menjadi pertimbangan di dalam proses penataan ruang, baik pada proses perencanaan, pemanfaatan, maupun pengendalian

\footnotetext{
${ }^{2}$ Ibid.

${ }^{3}$ Ibid.
} 
pemanfaatan ruang untuk meminimalisir terjadinya konflik-konflik antar pihak yang berkepentingan. Oleh karenanya pemerintah perlu memfasilitasi agar penyampaian aspirasi masyarakat dalam penataan ruang dapat berjalan dengan efektif dan efesien.

Di dalam pembentukan perda sangat diperlukan keterbukaan pemerintah, dengan adanya keterbukaan pemerintah terhadap publik dimungkinkan keterlibatan masyarakat untuk berpartisipasi, baik dari proses perancangan peraturan sampai dengan diberlakukannya suatu peraturan. Partisipasi masyarakat dalam pembentukan peraturan perundang-undangan maupun perda dapat kita lihat dalam Pasal 96 Undang-Undang Republik Indonesia Nomor 12 Tahun 2011 tentang Pembentukan Peraturan Perundang-Undangan (UU No. 12-2011) bahwa masyarakat berhak memberikan masukan secara lisan atau tertulis dalam pembentukaan peraturan perundang-undangan. Masukan secara lisan dan/atau tertulis sebagaimana dimaksud tersebut dapat dilakukan melalui rapat dengar pendapat umum, kunjungan kerja, sosialisasi dan/atau, seminar, lokakarya dan/atau diskusi. Senada dengan hal tersebut, dalam Pasal 139 Ayat (1) UU No. 32-2004 juga terdapat ketentuan bahwa masyarakat berhak memberikan masukan secara lisan atau tertulis dalam rangka penyiapan atau pembahasan rancangan perda. Penjelasan Pasal 139 Ayat (1) tersebut menjelaskan bahwa hak masyarakat dalam ketentuan ini dilaksanakan sesuai dengan Peraturan Tata Tertib DPRD. Dari bunyi Pasal 96 UU No. 12-2011 dan Pasal 139 Ayat (1) UU No. 32-2004, serta penjelasannya dapat diketahui bahwa:

1. Masyarakat berhak memberikan masukan dalam rangka penyiapan atau pembahasan rancangan Perda;

2. Masukan masyarakat tersebut dapat dilakukan secara lisan atau tertulis; dan

3. Hak masyarakat tersebut dilaksanakan sesuai dengan Peraturan Tata Tertib DPRD.
Dengan demikian, partisipasi masyarakat dalam penyusunan perda merupakan hak masyarakat, yang dapat dilakukan baik dalam tahap penyiapan maupun tahap pembahasan. Dalam konteks hak asasi manusia, setiap hak pada masyarakat menimbulkan kewajiban pada pemerintah sehingga haruslah jelas pengaturan mengenai kewajiban pemerintahan daerah untuk memenuhi hak atas partisipasi masyarakat dalam penyusunan perda tersebut. Dari penjelasan pasal-pasal diatas dapat diketahui bahwa kewajiban tersebut ada pada DPRD. Hal ini terindikasikan dari penjelasan bahwa "hak masyarakat dalam ketentuan ini dilaksanakan sesuai dengan Peraturan Tata Tertib DPRD”. Berdasarkan penjelasan tersebut, partisipasi masyarakat dalam penyusunan perda hanya pada tahap penyiapan dan pembahasan rancangan perda di DPRD. Sedangkan dapat diketahui bahwa tahap penyiapan rancangan perda tidak sepenuhnya dapat dilaksanakan sesuai dengan Peraturan Tata Tertib DPRD. Oleh karena, penyiapan rancangan perda dapat juga dilakukan oleh kepala daerah, seperti pada rancangan perda tentang APBD hanya berasal dari kepala daerah. Sehingga masih memerlukan kejelasan mengenai kewajiban untuk memenuhi hak masyarakat berpartisipasi dalam pembentukan perda, baik pada tahap penyiapan maupun pembahasan.

Berbicara mengenai pembentukan suatu peraturan atau kebijakan yang dibentuk oleh pemerintah yang berwenang dalam hal ini Kepala daerah dan DPRD sangat diperlukan keterlibatan masyarakatnya, seperti yang telah diuraikan sebelumnya. Dalam pelaksanaannya kadang masih terdapat berbagai penafsiran tentang siapa yang dimaksud dengan istilah masyarakat, ada yang mengartikan setiap orang pada umumnya, setiap orang atau lembaga yang terkait, atau setiap lembaga swadaya masyarakat.

Maria Farida Indrati S. berpendapat bahwa masyarakat adalah setiap 
orang pada umumnya terutama masyarakat yang "rentan" terhadap peraturan tersebut, setiap orang atau lembaga terkait, atau setiap lembaga swadaya masyarakat yang terkait. ${ }^{4}$ Mengenai sejauh mana masyarakat tersebut dapat ikut serta dalam pembentukan peraturan perundang-undangan (dalam hal ini UU dan perda), hal tersebut dapat tergantung pada keadaan dari pembentuk perundang-undangan sendiri oleh karena UUD NRI 1945 dan berbagai peraturan perundang-undangan telah menetapkan lembaga mana yang dapat membentuk peraturan perundang-undangan tersebut. Akan tetapi keterlibatan masyarakat untuk ikut serta dalam pembentukan suatu peraturan perundang-undangan akan menjadi lebih efisien sesuai dengan harapan kita bersama untuk mencapai suatu pemerintahan yang baik (good governance). Apabila suatu perda telah dapat menampung aspirasi masyarakat luas tentunya peran serta masyarakat tersebut tidak akan terlalu dipaksakan pelaksanaannya. Oleh karena itu diperlukan peningkatan kualitas anggota DPRD maupun seluruh jajaran pemerintah yang mempunyai tugas membentuk suatu Perda.

Perencanaan pembangunan dalam hal ini, adanya suatu proses partisipasi masyarakat tidaklah mudah, meskipun dijumpai dalam praktik ada proses yang diawali dengan musyawarah rencana pembangunan kelurahan, musyawarah pembangunan kota sampai pada tahap penetapan perencanaan detail pembangunan daerah hal tersebut belum dapat menjamin diprioritaskannya kebutuhan publik. Kenyataannya ruang partisipasi ke arah itu belum maksimal, karena orang-orang yang di undang untuk hadir adalah orang-orang yang dekat dengan birokrasi dan/atau kekuasaan. Disamping itu dalam penyusunan program pembangunan terkesan dipaksakan tanpa melibatan publik.

\footnotetext{
${ }^{4}$ Maria Farida Indrati S. 2007. Ilmu Perundangundangan. Yogyakarta, Kanisius, hlm. 262-265.
}

\begin{abstract}
Keterlibatan masyarakat dalam proses perencanaan pembangunan, perencanaan pembentukan kebijakan, pemantauan dari hasil pembangunan dan keberlakuan suatu kebijakan, adalah suatu hal yang mendorong suksesnya suatu pembangunan yang efektif dan efisien.
\end{abstract}

Mendorong masyarakat untuk berpartisipasi dalam proses pembangunan itu sendiri merupakan permasalahan yang perlu dicari pemecahannya. Mendorong, bukan mengharuskan partisipasi masyarakat seperti halnya mendorong rakyat untuk mau berkorban, juga membutuhkan insentifinsentif sendiri. Tidak cukup kita mengatakan bahwa karena pembangunan tersebut untuk masyarakat, maka adalah mutlak apabila rakyat harus mau berpartisipasi dalam pembangunan. Pengalaman pembangunan membuktikan bahwa sering kali pembangunan yang dikatakan untuk kepentingan rakyat ternyata tidak sesuai dengan harapan masyarakat. Dalam hal ini hambatan yang ditemui atau dihadapi di lapangan dalam usaha melaksanakan proses pembangunan yang partisipatif adalah belum dipahaminya makna sebenarnya dari konsep partisipasi oleh pihak perencana dan pelaksana pembangunan. Definisi partisipasi yang berlaku di kalangan lingkungan aparat perencana dan pelaksana pembangunan adalah kemauan masyarakat untuk mendukung secara mutlak program-program pemerintah yang dirancang dan ditentukan tujuannya oleh pemerintah. Di lapangan para perencana dan pelaksana menggunakan suatu konsep hierarkis dalam melakukan seleksi proyek pembangunan.

Proyek-proyek pembangunan yang berasal dari pemerintah diistilahkan sebagai proyek pembangunan yang diusulkan oleh masyarakat, sedang proyek pembangunan yang diusulkan oleh masyarakat dianggap sebagai keinginan. Karena merupakan "kebutuhan" maka proyek pemerintah itu harus dilaksanakan. Sedangkan, karena proyek yang diusulkan oleh masyarakat 
hanya berupa keinginan maka proyek itu pun memperoleh prioritas yang rendah.

Proses partisipatif harus dilakukan, karena masyarakat adalah pihak yang paling mengetahui tentang dirinya dan permasalahannya yang melingkupinya. Tanpa keterlibatan masyarakat, maka pembangunan tidak akan berdampak signifikan bagi perbaikan kualitas hidup rakyat seperti perbaikan infrastruktur untuk pelayanan publik dan pengentasan rakyat dari kemikinan.

\section{B. PEMBAHASAN}

\section{Pelaksanaan Partisipasi Masyarakat Dalam Pembentukan Suatu Peraturan Daerah}

Partisipasi masyarakat merupakan salah satu bentuk partisipasi politik masyarakat yang sangat penting dalam rangka menciptakan good governance. Partisipasi masyarakat dalam pembentukan peraturan perundang-undangan (perda) dapat kita lihat dalam Pasal 96 Ayat (1) dan Ayat (2) UU No. 12-2011 yang menyatakan bahwa masyarakat berhak memberikan masukan secara lisan dan/atau tertulis dalam pembentukaan peraturan perundangundangan. Masukan secara lisan dan/atau tertulis sebagaimana dimaksud tersebut dapat dilakukan melalui rapat dengar pendapat umum, kunjungan kerja, sosialisasi dan/atau seminar, lokakarya dan/atau diskusi. Senada dengan hal tersebut, dalam Pasal 139 Ayat (1) UU No. 32-2004 juga terdapat ketentuan bahwa masyarakat berhak memberikan masukan secara lisan atau tertulis dalam rangka penyiapan atau pembahasan rancangan perda.

Konsep partisipasi terkait dengan konsep demokrasi, sebagaimana dikemukakan oleh Philipus M. Hadjon bahwa di tahun 1960 muncul konsep demokrasi partisipasi. Dalam konsep ini rakyat mempunyai hak untuk ikut memutuskan dalam proses pengambilan keputusan pemerintahan. Dalam sebagaimana dikemukakan oleh Burkens dalam buku yang berjudul "Beginselen van de democratische rechtsstaat" bahwa: ${ }^{5}$

1. Pada dasarnya setiap orang mempunyai hak yang sama dalam pemilihan yang bebas dan rahasia;

2. Pada dasarnya setiap orang mempunyai hak untuk dipilih;

3. Setiap orang mempunyai hak-hak politik berupa hak atas kebebasan berpendapat dan berkumpul;

4. Badan perwakilan rakyat mempengaruhi pengambilan keputusan melalui sarana "(mede) beslissing-recht" (hak untuk ikut memutuskan keputusan dan atau melalui wewenang pengawas;

5. Asas keterbukaan dalam pengambilan keputusan dan sifat keputusan yang terbuka;

6. Dihormatinya hak-hak kaum minoritas. Asas keterbukaan sebagai salah satu syarat minimum dari demokrasi terungkap pula dalam pendapat Couwenberg dan Sri Soemantri Mertosoewignjo.

Sedangkan Sri Soemantri M, mengemukakan bahwa ide demokrasi menjelmakan dirinya dalam lima hal, dua diantaranya adalah: pemerintah harus bersikap terbuka (openbaarheid van bestuur) dan dimungkinkannya rakyat yang berkepentingan menyampaikan keluhannya mengenai tindakan-tindakan pejabat yang dianggap merugikan. ${ }^{6}$

Dari penjelasan tersebut di atas jelas menunjukan bahwa dalam proses pengambilan keputusan, termasuk pengambilan keputusan dalam bentuk perda, terdapat hak masyarakat untuk berpartisipasi dalam proses penyusunan perda yaitu memberi masukan secara lisan dan/atau

\footnotetext{
5 Mahendra Putra Kurnia, dkk. 2007. Pedoman Naskah Skademik PERDA Partisipatif (Urgensi, Strategi, dan Proses Bagi Pembentukan Perda yang Baik). Yogyakarta, Kreasi Total Media (KTM), hlm. 22.

${ }^{6}$ Sri Soemantri M. 1992. Bunga Rampai Hukum Tata Negara Indonesia. Bandung, Alumni, hlm. 29.
} 
tertulis dalam persiapan maupun pembahasan rancangan perda.

Menurut Sad Dian Utomo manfaat partisipasi dalam pembuatan kebijakan publik, termasuk dalam pembuatan perda adalah: ${ }^{7}$

1. Memberikan landasan yang lebih baik untuk pembuatan kebijakan publik.

2. Memastikan adanya implementasi yang lebih efektif karena warga mengetahui dan melihat dalam pembuatan kebijakan publik.

3. Meningkatkan kepercayaan warga kepada eksekutif dan legislatif.

4. Efisiensi sumber daya, sebab dengan keterlibatan masyarakat dalam pembuatan kebijakan publik dan mengetahui kebijakan publik, maka sumber daya yang digunakan dalam sosialisasi kebijakan publik dapat dihemat.

Selama ini peran masyarakat dalam proses pembentukan perda masih bersifat parsial dan simbolik. Beberapa komunikasi massa yang dilakukan hanyalah sebagai pelengkap prosedur adanya basic research (penelitian dasar) yang melandasi perencanaan pembentukan perda. Sementara dalam tahap perancangan pembahasan dilakukan oleh unit kerja dinas dari pemerintah atau oleh panitia khusus dari DPRD (ahap ini melibatkan akademis atau pakar-pakar yang kompeten di bidangnya). TerdapatAda 8 prinsip yang diungkapkan oleh Rival G. Ahmad mengenai optimalisasi partisipasi masyarakat dalam pembentukan perda, yaitu: ${ }^{8}$

a. Adanya kewajiban publikasi yang efektif.

7 Indra J. Piliang. 2003. dkk, Otonomi Daerah: Evaluasi dan Proyeksi. Jakarta, Yayasan Harkat Bangsa, hlm 267-272.

8 Sirajuddin, dkk. 2006. Legislative Drafting: Pelembagaan Metode Partisipatif dalam Pembentukan Peraturan Perundang-undangan. Malang, Malang Corruption Watch dan YAPPIKA, hlm. 89. b. Adanya kewajiban informasi dan dokumentasi yang sistematis, debas dan aksesabel.

c. Adanya jaminan prosedur dan forum yang terbuka dan efektif bagi masyarakat untuk terlibat dalam mengawasi proses sejak perencanaan.

d. Adanya prosedur yang menjamin publik bisa mengajukan RUU selain anggota DPRD dan Pemerintah.

e. Adanya pengaturan yang jelas mengenai dokumen dasar yang wajib tersedia dan aksesabel seperti naskah akademik dan Raperda.

f. Adanya jaminan banding bagi publik bila proses pembentukan perda tidak dilakukan secara partisipatif.

g. Ada pengaturan jangka waktu yang memadai untuk seluruh proses penyusunan, pembahasan Raperda dan diseminasi perda yang telah dilaksanakan.

h. Ada pertanggung jawaban yang jelas dan memadai bagi pembentukan peraturan daerah yang dengan sengaja menutup peluang masyarakat untuk berpartisipasi

Pemerintahan yang baik dan demokratis harus menjamin terealisasinya prinsip-prinsip tersebut. Bentuk upaya menjaring partisipasi masyarakat yang dapat dilakukan oleh pembentukan perda yaitu melakukan penelitian terpadu sebelum perancangan perda, menggelar rapat dengar pendapat umum materi yang akan diajukan dan memberi kesempatan warga mengikuti persidangan di Kantor DPRD (dengan membuka informasi jadwal sidang pembentukan perda). Apabila pemerintah telah memenuhi kewajiban untuk memfasilitasi partisipasi masyarakat, maka masyarakat harus mampu secara aktif dan efektif menggunakan haknya untuk melakukan pengawasan, memantau DPRD atau Partai politik sehingga masyarakat dapat menjadi kekuatan kontrol tersendiri. ${ }^{9}$

9 Suwidi Tono. 2003. Kita Lebih Bodoh dari Generasi Soekarno-Hatta. Jakarta, Vision 03 Jakarta, hlm. 185. 
Terdapat beberapa prinsip dasar dalam proses penyusunan perda yaitu:

1. Transparansi/keterbukaan. Proses yang transparan memberikan kepada masyarakat: (a) informasi tentang akan ditetapkan suatu kebijakan, dan (b) peluang bagi masyarakat untuk memberikan masukan dan melakukan pengawasan terhadap pemerintah. Hal penting dalam proses pengambilan keputusan adalah bahwa kegiatan ini membuka kesempatan bagi masyarakat untuk dapat memberikan masukan dan pertimbangan kepada pemerintah secara langsung. Proses yang transparan haruslah mampu meniadakan batas antara pemerintah dan non pemerintah.

2. Partisipasi. Partisipasi mendorong: (a) terciptanya komunikasi publik untuk meningkatkan pemahaman masyarakat terhadap proses pengambilan keputusan pemerintah, dan (b) keterbukaan informasi pemerintah yang lebih baik untuk kemudian menyediakan gagasan baru dalam memperluas pemahaman komprehensif terhadap suatu isu. ${ }^{10}$ Partisipasi mengurangi kemungkinan terjadinya konflik dalam menerapkan suatu keputusan dan mendukung penerapan akuntabilitas, serta mendorong publik untuk mengamati apa yang dilakukan oleh pemerintah. Partisipasi publik tercermin dalam: (a) kesempatan untuk melakukan kajian terhadap rancangan keputusan; (b) kesempatan untuk memberikan masukan; dan (c) tanggapan terhadap masukan publik dari pengambil keputusan, dalam hal ini pemerintah.

3. Koordinasi dan keterpaduan berkaitan dengan hubungan antara pemerintah dan organisasi dalam pemerintah menyediakan mekanisme yang melibatkan instansi lain dalam

10 Kemilau Mutik. 2010. Kedudukan Naskah Akademik Dalam Proses Pembentukan Peraturan Daerah, Tesis, Fakultas Hukum Universitas Brawijaya, Malang, hlm. 27. pengambilan keputusan secara utuh. Keterpaduan memerlukan kombinasi yang harmonis antara wawasan dan aksi koordinasi, menekan konflik, membatasi ketidakefektifan, dan yang terpenting membatasi jumlah produk hukum.

Pada intinya, pembuatan perda sebenarnya merupakan satu bentuk pemecahan masalah secara rasional. Langkah pertama adalah menjabarkan masalah yang akan diatasi, dan menjelaskan bagaimana perda yang diusulkan akan dapat memecahkan masalah tersebut. Konsep atau draf rancangan perda harus merupakan usulan pemecahan masalah-masalah spesifik yang telah diidentifikasi dan dirumuskan. Draf perda juga hendaknya dikaji secara empiris melalui konsultasi publik dan pembahasan antar-instansi. Lebih jauh, rancangan perda yang sudah disahkan hanyalah merupakan pemecahan masalah secara teoritis. Sebagai pemecahan masalah, perda yang baru hendaknya dicek secara silang (cross check). Perda perlu diimplementasikan untuk mengetahui secara pasti tingkat keefektifan yang sebenarnya.

Beberapa hal yang dapat dilakukan dalam kaitannya dengan pelaksanaan peran serta masyarakat dalam pembentukan perda antara lain: dilakukannya rapat dengar pendapat umum atau rapat-rapat lainnya yang bertujuan menyerap aspirasi masyarakat, dilakukannya kunjungan oleh anggota DPRD untuk mendapat masukan dari masyarakat, ataupun diadakannya seminar-seminar atau kegiatan yang sejenis dalam rangka melakukan pengkajian atau menindaklanjuti berbagai penelitian untuk menyiapkan suatu rancangan perda. Akan tetapi dalam pelaksanaannya kadang masih terdapat berbagai penafsiran tentang siapa yang dimaksud dengan istilah masyarakat, ada yang mengartikan setiap orang pada umumnya, setiap orang atau lembaga yang terkait, atau setiap lembaga swadaya masyarakat. Mengenai sejauh mana masyarakat tersebut dapat ikut serta dalam pembentukan peraturan perundangundangan (dalam hal ini UU dan Perda), hal 
tersebut dapat tergantung pada keadaan dari pembentuk perundang-undangan sendiri oleh karena UUD NRI 1945 dan berbagai peraturan perundang-undangan telah menetapkan lembaga mana yang dapat membentuk peraturan perundang-undangan tersebut. Apabila suatu perda telah dapat menampung aspirasi masyarakat luas tentunya peran serta masyarakat tersebut tidak akan terlalu dipaksakan pelaksanaannya. Oleh karena itu diperlukan peningkatan kualitas anggota DPRD maupun seluruh jajaran pemerintah yang mempunyai tugas membentuk suatu perda.

\section{Hakekat Pentingnya Partisipasi Masyarakat Dalam Hal Pembentukan Peraturan Daerah RDTRdK}

Pembentukan perda merupakan bagian penting untuk melakukan pembentukan hukum di daerah dan merupakan esensi dari "legal formulation" yang harus diagendakan oleh pemerintah daerah dalam merencanakan pembangunan daerahnya. Dalam perencanaan detail tata ruang dan kawasan suatu daerah yang efektif dan efisien membutuhkan pengaturan hukum yang dituangkan dalam perangkat peraturan perundang-undangan (legal aspect) agar memiliki sifat yuridis-normatif maupun yuridis-sosiologis.

Maka perda yang dimaksudkan untuk memberikan landasan hukum untuk perencanaan tata ruang yang dituangkan dalam bentuk Perda Rencana Detail Tata Ruang dan Kawasan (RDTRdK) harus dipahami sebagai bagian konsepsi pembentukan hukum. Dengan demikian keberadaan hukum menjadi sesuatu yang sangat substansial secara teoritik dan paradigmatik bagi jalinan perencanaan pembangunan daerah dalam seluruh segmen penyelenggaraan pemerintahan negara. Pada prinsipnya dapat dikatakan bahwa melalui sarana perangkat hukum, perencanaan pembangunan daerah diharapkan memiliki dan menjamin terbangunnya suatu kondisi bermuatan ketertiban, kepastian, dan keadilan. Maka perda RDTRdK harus diterima sebagai instrumen untuk menjamin pembangunan suatu daerah yang memberi ketertiban, kepastian, dan keadilan tersebut.

$$
\text { Dengan perda RDTRdK }
$$
diagendakan bahwa suatu perencanaan pembangunan daerah mepunyai ketertiban, kepastian dan keadilan yang sesuai dengan kebutuhan daerah dalam rangka penyelenggaraan pemerintahan daerah yang otonom. Dengan pengaturan hukum dapat juga dipahami bahwa perencanaan pembangunan daerah harus dituangkan dalam suatu perda yang bermuatan norma perencanaan dengan memperhatikan perkembangan masyarakat (sociale dynamic). ${ }^{11}$

Tegasnya adalah bahwa melalui sarana peraturan daerah tentang RDTRdK sudah selayaknya perencanaan pembangunan suatu daerah dilakukan secara tepat dalam bingkai dinamika kemasyarakatan termasuk pengembangan hubungan pemerintahan antara pemerintah pusat dan daerah. ${ }^{12}$

Pada konteks penataan ruang, maka peran serta masyarakat dapat didefinisikan sebagai proses keterlibatan masyarakat yang memungkinkan mereka dapat mempengaruhi proses pengambilan keputusan penataan ruang yang meliputi keseluruhan proses sebagaimana disebutkan dalam Pasal 1 UU No. 26-2007 yaitu:

Pengaturan penataan ruang (Ayat (9)), pembinaan penataan ruang (Ayat (10)), pelaksanaan penataan ruang (Ayat (11)), dan pengawasan penataan ruang (Ayat (12)). Apabila pengertian peran serta masyarakat lebih pada proses mempengaruhi pengambilan keputusan dalam keseluruhan proses penataan ruang, maka tujuan utama peran serta masyarakat mencakup dua hal pokok: pertama, melahirkan output rencana yang lebih baik daripada dilakukan hanya

11 Alan Gart. 1994. Regulation. New York, John Wiley \& Sons, inc.

12 Muhammad Fauzan. 2006. Hukum Pemerintahan Daerah: Kajian tentang Hubungan Keuangan Antara Pusat dan Daerah. Yogyakarta, UII Press, hlm. 47-49. 
melalui proses teknokratis, dan kedua, mendorong proses capacity building masyarakat dan pemerintah. Output rencana tata ruang yang dihasilkan melalui proses partisipasi diharapkan dapat memperkecil derajat konflik antar berbagai stakeholders terutama pada tahap pemanfaatan dan pengendalian pemanfaatan ruang. Disamping itu, peran serta masyarakat dapat memberikan kontribusi agar menghasilkan rencana tata ruang yang lebih sensitif dan lebih mampu mengartikulasikan kebutuhan berbagai kelompok masyarakat yang beragam dengan tidak mengenyampingkan kearifan lokal.

Pada sisi lainnya, peran serta masyarakat dimaksudkan sebagai proses pembelajaran masyarakat dan pemerintah yang secara langsung dapat memperbaiki kapasitas mereka dalam mencapai kesepakatan. Tidak dipungkiri bahwa rencana tata ruang pada dasarnya merupakan kesepakatan berbagai stakeholders yang dilahirkan melalui serangkain dialog yang konstruktif dan berkelanjutan. Melalui proses dialog yang terus menerus sepanjang keseluruhan proses penataan ruang, maka akan terjadi proses pembelajaran bersama dan pemahaman bersama (mutual understanding) berbagai pihak tentang penataan ruang. Sehingga proses ini secara langsung akan berkontribusi terhadap proses pembinaan penataan ruang.

\section{Mekanisme Peran Serta Masyarakat Dalam RDTRdK Berkelanjutan}

Mencermati peran serta masyarakat yang sejalan dengan UU No. 26-2007 di dalamnya mencakup empat kegiatan utama yaitu pengaturan, pembinaan, pelaksanaan dan pengawasan penataan ruang. Keempat ruang lingkup tersebut lebih luas dari ruang lingkup yang disebutkan dalam Peraturan Pemerintah Republik Indonesia Nomor 68 Tahun 2010 tentang Bentuk dan Tata Cara Peran Masyarakat dalam Penataan Ruang (PP No. 68-2010) yang hanya mencakup tiga hal yaitu perencanaan, pemanfaatan, dan pengendalian penataan ruang.
Mekanisme peran serta masyarakat dilakukan sesuai dengan tahapan kegiatan penataan ruang. Secara umum mekanisme tersebut dapat berbentuk penyampaian informasi, usul dan saran lisan maupun tulisan melalui berbagai media informasi sesuai dengan perkembangan teknologi yang ada (media cetak dan elektronik, seminar, workshop, konsultasi publik, brosur, kegiatan budaya, laman, kegiatan pameran, rapat dengar pendapat umum dengan masyarakat) kepada lembaga-lembaga yang berwenang; dan keterlibatan secara langsung dalam kegiatan penataan ruang, misalnya sebagai salah satu wakil masyarakat yang terlibat dalam penyusunan RDTRdK. Selain upaya-upaya yang bersifat individual, mekanisme peran serta dapat dilakukan oleh kelompok dan organisasi masyarakat serta organisasi profesi yang melakukan advocacy planning kepada lembaga-lembaga yang berwenang.

Pelaksanaan peran serta masyarakat dilakukan bisa melalui lokakarya atau konsultasi publik untuk menjaring aspirasi masyarakat yang dilakukan secara bertahap. Tahap pertama lokakarya bisa dilakukan lebih dari satu kali untuk setiap daerah kabupaten/kota. Pada tahap ini setiap warga kabupaten/kota dapat menghadiri acara lokakarya/konsultasi tersebut yang diselenggarakan oleh Pemda. Output workshop pertama adalah serangkaian isuisu yang terkait pengaturan RDTRdK. Pada tahap ini juga ditentukan wakil-wakil masyarakat yang dapat mengikuti tahap kedua. Tahap kedua merupakan lokakarya atau konsultasi publik pada skala propinsi yang akan mendiskusikan lebih lanjut hasilhasil diskusi pada tahap pertama. Apabila pada tahap pertama, masyarakat mengemukakan masalah pengaturan penataan ruang pada skala yang lebih kecil, maka pada tahap kedua, isu yg akan dibicarakan akan meliputi masalah-masalah pada skala yang lebih luas (propinsi). Pada tahap kedua ini, peserta dapat dibagi dalam beberapa kelompok berdasarkan isu-isu spesifik yang telah dihasilkan pada tahap 
pertama untuk mempertajam isu dan memperoleh informasi dan tanggapan dari pihak eskekutif dan legislatif. Lokakarya bisa dilakukan lebih dari satu kali tergantung kebutuhan. Bahan yang telah dihasilkan pada kedua tahap lokakarya ini menjadi masukan penting bagi pihak eksekutif dan legislatif dalam penyusunan perda pengaturan penataan ruang. Selain melalui workshop, aspirasi dapat dilakukan secara tertulis, lisan, dan perantara teknologi yang ada (pesan teks, surat elektronik, laman, forum-forum sosial masyarakat melalui ranah daring) kepada pihak eksekutif dan legislatif yang memiliki kewenangan dalam menyusun dan menetapkan keputusan.

\section{P E N U T U P}

\section{Kesimpulan}

Bahwa pelaksanaan partisipasi masyarakat dalam pembentukan suatu perda dapat dilakukan dengan

a. Memberikan masukan-masukan atau pendapat-pendapat dalam rapat dengar pendapat umum atau rapat-rapat lainnya yang sejenis.

b. Memberikan masukan-masukan kepada anggota DPRD pada saat melakukan kunjungan kerja.

c. Mengikuti seminar-seminar atau kegiatan yang sejenis dalam rangka melakukan pengkajian atau menindaklanjuti berbagai penelitian untuk menyiapkan suatu rancangan peraturan daerah.

d. Peran serta masyarakat dalam penataan ruang menjadi hal yang sangat penting dalam rangka menciptakan wilayah yang aman, nyaman, produktif dan berkelanjutan dengan dibangun berdasarkan kearifan lokal yang mengutamakan kepentingan masyarakat.

\section{Saran}

Berdasar hal tersebut diatas, maka terdapat beberapa hal yang harus diperhatikan, yaitu: a. Menempatkan posisi masyarakat sesuai dengan hak dan kewajibannya sebagai pelaku pembangunan wilayah dengan difasilitasi oleh pemerintah.

b. Meningkatkan upaya-upaya untuk mendorong public awarness, public services, dan public campaign.

c. Mendorong dan meningkatkan terus fungsi kelembagaan penataan ruang yang efektif yang dapat mengakomodasi kepentingan masyarakat dalam penyelenggaraan penataan ruang.

d. Mengadakan lomba penulisan karya ilmiah berupa essai, kajian teori ataupun penulisan jurnal dalam rangka mematangkan konsep rancangan peraturan daerah.

\section{DAFTAR PUSTAKA}

Axelrod, R.M. 1984. The Evolution of Cooperation. New York, Basic Books.

Fauzan, Muhammaad. 2006. Hukum Pemerintahan Daerah: Kajian tentang Hubungan Keuangan Antara Pusat dan Daerah. Yogyakarta, UII Press.

Gart, Alan. 1994. Regulation. New York, John Wiley \& Sons, inc.

Maria Farida Indrati S, Maria Farida. 2007. Ilmu Perundang-undangan. Yogyakarta, Kanisius.

Mutik, Kemilau. 2010. Kedudukan Naskah Akademik Dalam Proses Pembentukan Peraturan Daerah, Tesis, Fakultas Hukum Universitas Brawijaya, Malang.

Piliang, Indra J, dkk. 2003. Otonomi Daerah: Evaluasi dan Proyeksi. Jakarta, Yayasan Harkat Bangsa.

Putra Kurnia, Mahendra, dkk. 2007. Pedoman Naskah Skademik PERDA Partisipatif (Urgensi, Strategi, dan Proses Bagi Pembentukan Perda yang Baik), 
Yogyakarta, Kreasi Total Media (KTM).

Sirajuddin, dkk. 2006. Legislative Drafting: Pelembagaan Metode Partisipatif dalam Pembentukan Peraturan Perundang-undangan. Malang, Malang Corruption Watch dan YAPPIKA.

Soekarwo. 2005. Hukum Pengelolaan Keuangan Daerah Berdasarkan Prinsip-Prinsip Good Financial Governance. Surabaya, Airlangga University Press.

Soemantri M, Sri. 1992. Bunga Rampai Hukum Tata Negara Indonesia. Bandung, Alumni

Tono, Suwidi. Kita Lebih Bodoh dari Generasi Soekarno-Hatta. Jakarta, Vision 03. 